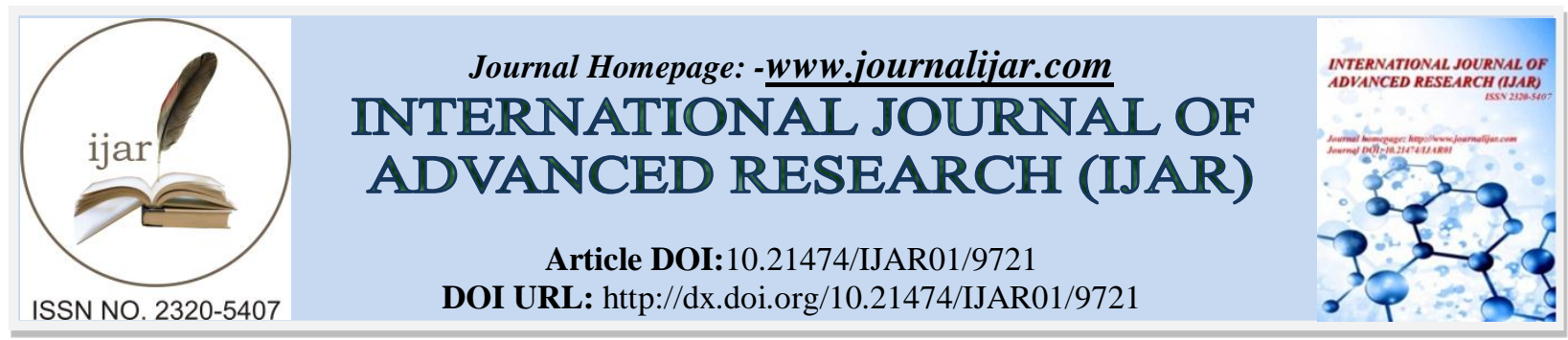

RESEARCH ARTICLE

\title{
CERVICAL ECTOPIC PREGNANCY WITH INVASIVE MOLAR CHANGES(A RARE CASE REPORT).
}

\section{Dr Nirmala Sharma ${ }^{1}$, Dr Aushima Vijay ${ }^{2}$ and DrJaswant Rai ${ }^{3}$.}

1. Senior Professor and unit head, Dept. of obs.\& Gyn., Govt. medical college and associated group of hospitals (Jay Kay Lon), kota.

2. Assistant professor, Dept. of obs.\& Gyn., Govt. medical college and associated group of hospitals(Jay Kay Lon), kota.

3. Resident, Dept. of obs.\& Gyn., Govt. medical college and associated group of hospitals,(Jay Kay Lon), kota.

\section{Manuscript Info}

[........................

Manuscript History

Received: 09 July 2019

Final Accepted: 12 August 2019

Published: September 2019

\section{Abstract}

Ectopic pregnancy occurs when the developing blastocyst get implanted at a site other than the endometrium of the uterine cavity. Cervical Molar pregnancy is a rare variety of ectopic molar pregnancy. Incidence of cervical ectopic pregnancy is $<1 \%$ of all ectopic pregnancies and it constitutes spectrum from gestational trophoblastic diseases. A 25-year-old primigravida brought from a remote place with complaints of 6-weeks of amenorrhea,generalized weakness, vomiting, pain in lower abdomen and profuse bleeding per vaginum since last 15 days. She has history of consumption of MTP pills over the counter twice. Evacuation was done thrice at various centers for the same but because of continuation of same symptoms patient was referred to higher center.

In our center, Pelvic examination revealed a normal-sized uterus with ballooning of cervix and significant bleeding per vaginum. Hence patient was taken for laparotomy followed by life saving TransAbdominal hysterectomy with Unilateralsalpingo-oophorectomy. Sample sent for Histo-pathological examination. Patient kept in High density unit for observation. Routine post operative care given, post op period was uneventful. Now patient on oral methotrexate and proper follow up with serial $\beta$-HCG\& Chest $X$ ray and Ultrasonography monitoring. HPE report suggestive of Cervical ectopic pregnancy with invasive molar changes.

Copy Right, IJAR, 2019,. All rights reserved.

\section{Introduction:-}

Ectopic pregnancy occurs when the developing blastocyst becomes implanted at a site other than the endometrium of the uterine cavity . Its prevalance ranges from 6 to $16 \%$ [1].]. Previous ectopic pregnancy, tubal pathology and surgery, in-utero DES exposure, previous genital infections, intrauterine devices, infertility, multiple sexual partners, smoking, in vitro fertilization, vaginal douching, age are known risk factors for ectopic pregnancy. Cervical pregnancy is a rare form of ectopic pregnancy in which the trophoblast implants in the cervical tissue of the endocervical canal. Cervical pregnancy incidence is approximately 1/9000 [2,3]. Although the etiology is still unknown, there is evidence for its association with cervico-uterine instrumentation [2], and in particular vaginal termination of pregnancy [4].

Corresponding Author:-DrAushima Vijay.

Address:-Assistant professor, Dept. of obs.\& Gyn., Govt. medical college and associated group of hospitals(Jay Kay Lon), kota. 
Gestational trophoblastic disease is a proliferative disorder of trophoblastic cells. It defines a heterogeneous group of interrelated lesions arising from the trophoblastic epithelium of the placenta. Whereas the incidence of hydatidiform molar pregnancy. In India it is 1 in 400 . Molar changes in the cervical pregnancy are very rare occurrence only $<1 \%$. The World Health Organization (WHO) classification of gestational trophoblastic disease includes complete and partial hydatiform mole, invasive mole, chorioncarcinoma, placental site trophoblastic tumor, epitheloid trophoblastic tumor, exaggerated placental site and placental site nodule [4]. Hydatiform molar degeneration of the placenta tissue can be classified in partial and complete hydatiform mole pregnancy. Risk factors for the development of hydatiform molar pregnancy are maternal age, history of previous molar pregnancy, smoking, alcohol abuse, oral contraceptives [5,6]. Normally molar pregnancy presents in the first trimester and is associated with a wide array of clinical symptoms, most commonly vaginal bleeding in combination with excessive $\beta$-HCG levels. However at the time of presentation, $60 \%$ of molar gestation had ruptured [7]. Cervical hydatiform molar pregnancy is not common and only four case reports are presented in the literature [8-11]. Here is a presentation of one more case of cervical molar pregnancy in a 25 year old woman.

\section{Case Presentation}

A 25-year-old Sikh primigavida came to the Jay Kay Lon hospital in emergency with complaining of vomiting, pain in lower abdomen and bleeding per vaginum since last 3 days with a history of 6-weeks of amenorrhea. She had MTP pills, 2 times without any prescription. She was off $\&$ on barrier contraceptive user. On examination, her vitals were Blood pressure was 90/60 and pulse rate was $110 / \mathrm{min}$, with severe degree of pallor. Per abdomen examination shows soft slight distension in lower abdomen.Per vaginal examination showed a normal-sized uterus and ballooning of cervix and bleeding.

Her hemoglobin on admission was $4 \mathbf{g m} / \mathbf{d l}$ and the urine pregnancy test was weak positive. Trans-abdominal ultrasonography confirmed the finding of a distended cervix with multiple tiny anechoic structures filling the dilated cervical canal. She had undergone few serial Dilatation \& Evacuations in different centers which was done for Retain Products of Conception. Then she had another bout of bleeding per vaginum and $3^{\text {rd }}$ time $\mathrm{D} \& \mathrm{E}$ done for the same complaint. Patient was referred to us and USG pelvis was done which showed uterine mass in lower uterine segment. Upper segment was empty. Again D\&E done.Patient was bleeding profusely. Keeping in view the above findings, decision for laparotomy was made. Abdominal Hysterectomy with Unilateral salpingo-oopherectomy done after the consent of the patient and relatives. Specimen sent for HPE.

\section{Histo-pathological Report -}

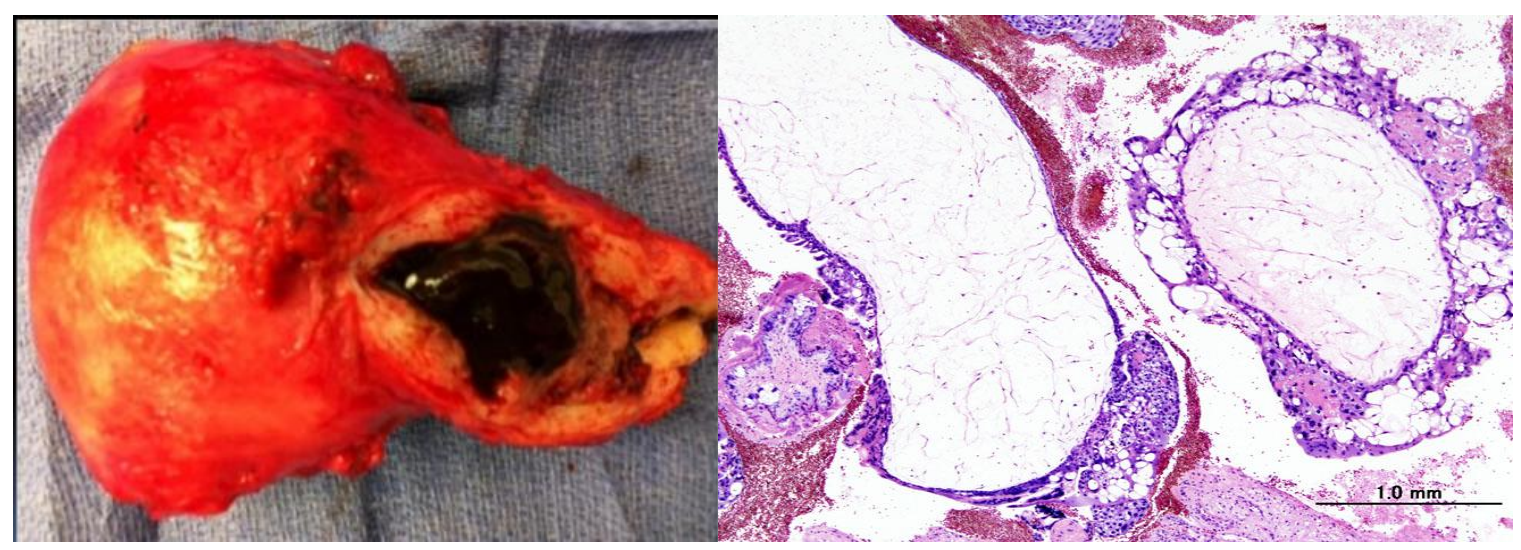

\section{Uterus- cavity empty}

Cervix- Cervical ectopic pregnancy with myometrial invasion suggestive of invasive mole.

1. Now Patient is on oral methotrexate in department of oncologywith serial B-HCG monitoring.

2. During the entire course- Patient had 8 units of blood transfusions. 4 units Fresh frozen plasma transfused prophylactically for management of DIC.

3. Post Operative $\beta-\mathrm{hCG}$ level was $6000 \mathrm{mU} / \mathrm{ml}$.(pre op data not available) 


\section{Discussion:-}

Clinically, tubal molar pregnancy mimics normal tubal ectopic pregnancy and, therefore, makes the diagnosis difficult (3). However, provisional diagnosis is made during surgery and histopathological examination can determine the final diagnosis.

Molar changes may even be found in cervical pregnancies (4, 5). Molar changes can be detected by transvaginalcolor Doppler ultrasonography and MRI.

Monitoring $\beta$-hCGtiters following conservative management of suspected ectopic pregnancies is important, not only to diagnose persistent ectopic gestation, but also to rule out the presence of malignant trophoblastic diseases (11). The current trend in the treatment of ectopic pregnancies is through conservative surgery and monitoring of $\beta$ hCGtiters to avoid missing a choriocarcinoma developing in an ectopic gestation, even though this is a very rare condition. Mediastinal metastasis of choriocarcinomas following ectopic pregnancies cause dyspnoea, pleural effusion and thoracic pain.

One extensive study on routine pre-evacuation ultrasound diagnosis of hydatidiform mole suggests that ultrasonography identifies less than $50 \%$ of hydatidiform moles. Detection rates are, however, higher for complete compared to partial moles, and improve even further after the $14^{\text {th }}$ week of gestation.

Incomplete abortion mimic A differencial diagnosis.

Histopathological examination of conception products remains the current gold standard for the diagnosis of gestational trophoblastic neoplasia. There is also a possibility of over-diagnosis by histological examination, especially in early ectopic tubal pregnancies, due to a more florid extra-villous trophoblastic proliferation compared with evacuated uterine products of conception. Extra caution should be taken to strictly apply the morphological criteria of circumferential trophoblastic proliferation, hydropic changes, scalloped villi and stromal karyorrhexis for diagnosis.

\section{Conclusion:-}

Ectopic molar pregnancy is a rare condition, which can occur at any place in the pelvic cavity. Invasive mole and choriocarcinoma might even follow such a pregnancy. However, ultrasonography might not be able to fully diagnose ectopic molar pregnancies, leaving histopathological examination of the conception products the current gold standard for the diagnosis.

MTP pills should not be given without any ultrasound scan evaluation.

Serial $\beta-H C G$ is helpful in suspected cases of Ectopic and Molar pregnancy.

\section{Refernce:-}

1. Murray H, Baakdah H, Bardell T, Tulandi T. Diagnosis and treatment of ectopic pregnancy. CMAJ 2005; 173: 905.

2. Ushakov FB, Elchalal U, Aceman PJ, Schenker JG: cervical pregnancy: past and future. ObstetGynecolSurv 1997; 52: 45-59

3. Vela G, Tulandi T. Cervical pregnancy: the importance of early diagnosis and treatment. J minim invasive gynecol 2007; 14: 481

4. Shih IE, Kurman RJ. Molecular basis of gestational trophoblastic disease.CurrMol Med 2002; 2: 1-12

5. Altieri A, Francecshi S, Ferlay J, Smith J, La Vecchia C. Epidemiology and aetiology of gestational trophoblastic diseases. Lancet Oncol 2003; 4: 670-8

6. Garner EL, Goldstein DP,Feltmate CM, Berkowitz RS. Gestational trophoblastic disease.ClinObstetGynecol 2007; 50: 22-112

7. Gillespie AM, Lidbury EA, Tidy JA, Hancock BW. The clinical presantation, treatment and outcome of

8. patients diagnosed with possible ectopic molar gestation. Int J Gynecol Cancer 2004; 14: 366-369.

9. Chapman K. Cervical pregnancy with hydatidiform mole. ActaObstetGynecol Scand. 2001; 80: 657-658

10. Wee Hy, Tay EH, Soong Y, Loh Sf. Cervical hydatidiform molar pregnancy. Aust NZ J ObstetGynaecol 2003; 43: $473-474$ 
11. Aytan H, Caliskan AC, Demirturk F, Koseoglu RD. Cervical partial hydatidiform molar pregnancy. GynecolObstet Invest 2008; 66:142-4

12. Schwentner L, Schmitt W, Bartusek G, Kreinberg R, Herr D. Cervical hydatidiform mole pregnancy after missed abortion presenting with severe vaginal bleeding: case report and review of the literature. Eur $\mathbf{J}$ ObstetGynecolReprod Biol. 2011 ; 156: 9-11. 